\title{
all is water, and the world is full of gods \\ Lee Beavington
}

abstract a grain of sand

into pyramids of oxygen with silicon chambers

electron dance called by their covalence geometric

the atom reduced to numbers

and matter loses its meaning

in orbit around a spirit vacuum

infinity slips between my fingers

where have we stored the sacred?

passages in books no longer printed

stories 100 pages from the headlines

the voices of wild places silenced before they are heard

corporate synapses overriding a child's curiosity

nature parceled into lots that hold less

how can we see again?

open new eyes from behind the Cartesian eclipse

behold the gaze of the intimate alchemist

Descartes called wonder the first passion

so why is our lens invisible

to the enchantment of every atom?

the chemist sees gold as property

real estate listed in the table periodic

the water window refracts the numinous earth

transparent consciousness of our skin-shored ocean

these bodies vessels of salty seas

liquid limbs that enfold the impermanence of membranes 
a matter of time before our embodied earth turns back to its human soil and river roots

that grow through our liver and veins

look again at that grain of sand

its atoms encased in cloud and years of light

origins that lay in rocky towers a comet's throw away

question the quartz as something more than

patterns of the world's self-revelation

ask the sister-sun of her brother's galaxy

can gods be found in a grain of sand?

if there isn't a god in a grain

there is a story

and it is filled with untold stars 


\section{Bibliography}

Brown, D.J. (2006). Descartes and the passionate mind. Cambridge, England: Cambridge University Press.

Hadzigeorgiou, Y. (2014). On the value of wonder in science education. In K. Egan, A. Cant., \& G. Judson (Eds.), Wonder-full education: The centrality of wonder in teaching and learning across the curriculum. New York and London: Routledge.

Ingold, T. (2015), The materials of life, In Making: Anthropology, Archeology, Art and Architecture. New York: Routledge.

Irigaray, L. (1993). Wonder: A reading of Descartes, The passions of the soul. In C. Burke \& G. C. Gill (Trans.), An ethics of sexual difference (pp. 72-82). New York: Cornell University Press.

Tarnas, R. (1991). The passion of the Western mind: Understanding the ideas that have shaped our world view. New York: Harmony Books.

\section{Suggested Citation}

Beavington, L. (2015). All is water, and the world is full of gods. SFU Ed Review 2015. Available online at http://www.sfuedreview.org. 